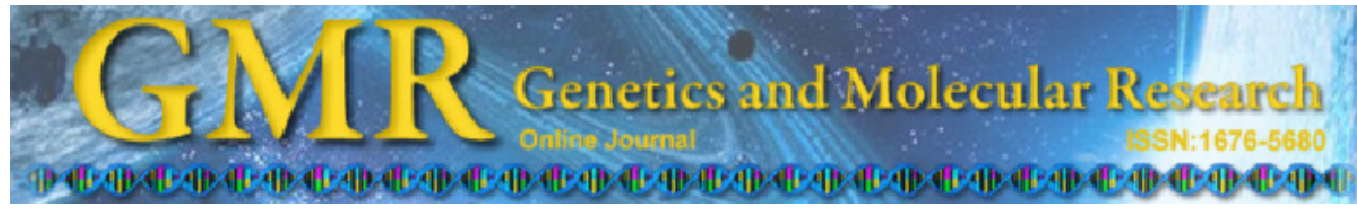

\title{
Comparative analysis of myostatin gene and promoter sequences of Qinchuan and Red Angus cattle
}

\author{
Y.L. He ${ }^{1,2 *}$, Y.H. Wu ${ }^{1,2 *}$, F.S. Quan ${ }^{1}$, Y.G. Liu ${ }^{1}$ and Y. Zhang ${ }^{1}$ \\ ${ }^{1}$ Key Laboratory of Animal Reproductive Endocrinology \& Embryo Engineering, \\ College of Veterinary Medicine, Northwest A\&F University, \\ Ministry of Agriculture, Yangling, China \\ ${ }^{2}$ Key Laboratory of Ministry of Education for Protection and Utilization \\ of Special Biological Resources in Western China, Ningxia University, \\ Yinchuan, China \\ *These authors contributed equally to this study. \\ Corresponding author: Y. Zhang \\ E-mail: zhy_56@126.com \\ Genet. Mol. Res. 12 (3): 3398-3406 (2013) \\ Received December 20, 2012 \\ Accepted April 17, 2013 \\ Published September 4, 2013 \\ DOI http://dx.doi.org/10.4238/2013.September.4.6
}

\begin{abstract}
To better understand the function of the myostatin gene and its promoter region in bovine, we amplified and sequenced the myostatin gene and promoter from the blood of Qinchuan and Red Angus cattle by using polymerase chain reaction. The sequences of Qinchuan and Red Angus cattle were compared with those of other cattle breeds available in GenBank. Exon splice sites were confirmed by mRNA sequencing. Compared to the published sequence (GenBank accession No. AF320998), 69 single nucleotide polymorphisms (SNPs) were identified in the Qinchuan myostatin gene, only one of which was an insertion mutation in Qinchuan cattle. There was a 16-bp insertion in the first 705-bp intron in 3 Qinchuan cattle. A total of 7 SNPs were identified in exon 3, in which the mutation occurred in the third base of the codon and was synonymous. On comparing the Qinchuan myostatin gene sequence to that of Red Angus cattle, a total of 50 SNPs were identified in the first and third exons. In addition, there were 18 SNPs identified in the Qinchuan cattle promoter region compared with those of other cattle
\end{abstract}


breeds (GenBank accession No. AF348479), but only 14 SNPs when compared to the Red Angus cattle myostatin promoter region.

Key words: Myostatin; Qinchuan cattle; Red Angus cattle; Promoter; SNPs

\section{INTRODUCTION}

Myostatin is a member of the transforming growth factor-beta superfamily of secreted growth and differentiation factors. Myostatin is a negative regulator of skeletal muscle development and growth (McPherron et al., 1997), and is most well known as a potent suppressor of muscle growth, development, and regeneration (Schuelke et al., 2004). Myostatin is therefore essential for the proper regulation of skeletal muscle mass (McPherron and Lee, 1997). Loss and congenital absence of myostatin function has been associated with an increase in muscle mass in mice (McPherron et al., 1997), humans (Schuelke et al., 2004), cattle (McPherron and Lee, 1997; Grobet et al., 1997; Kambadur et al., 1997; Grobet et al., 1998; Karim et al., 2000; Marchitelli et al., 2003; Joulia-Ekaza and Cabello, 2006), sheep (Clop et al., 2006; Boman et al., 2009; Boman and Våge, 2009), and dogs (Mosher et al., 2007). In Belgian Blue cattle, an 11-bp deletion of the myostatin gene results in a truncated protein, as transcription terminates 14 codons downstream of the mutation site (McPherron and Lee, 1997). In Piedmontese cattle, 2 single nucleotide polymorphisms (SNPs) have been identified (McPherron and Lee, 1997). Karim et al. (2000) and Smith et al. (2000) have described additional mutations in the myostatin gene in other cattle breeds. Three, 7, and 4 polymorphisms in exons 1, 2, and 3, respectively, were identified in Nellore cattle (Grisolia et al., 2009). In an analysis of the myostatin genes of Bos indicus and B. taurus, Tantia et al. (2006) identified SNPs and an insertion mutation in $B$. indicus. Baron et al. (2012) sequenced exon 2 of the myostatin gene in 332 horses of 20 different breeds and compared it against horse myostatin gene sequence deposited in GenBank. The obtained sequences revealed the presence of 11 haplotypes represented by 10 variable nucleotide mutations, 8 of which corresponded to amino acid sequence changes (Baron et al., 2012).

However, no studies on variation in the myostatin gene have yet been conducted on the Qinchuan breed, which is the main cattle breed used in China and has several favorable characteristics, including a tall body, good meat quality, genetic stability, and high adaptability, despite the presence of a congenital defect in which the hind legs are underdeveloped. In order to improve the meat production performance in Qinchuan breeds and to select for improved beef cattle breeds, we here evaluated the role of myostatin in cattle breed quality by comparing myostatin gene sequences in Qinchuan and Red Angus, an internationally famous breed, to those of other cattle breeds that are available in GenBank (accession No. AF320998).

\section{MATERIAL AND METHODS}

\section{Animal sources and DNA samples}

Samples were obtained from the Yang Ling Ke Yuan Cloning Co. Ltd. Genomic DNA samples were randomly selected from 16 Qinchuan cattle and 4 Red Angus cattle. Samples containing $6 \mathrm{~mL}$ whole blood were collected in siliconized vacuum tubes with $1 \mathrm{~mL}$ acid citrate dextrose solution. DNA was extracted from $200 \mu \mathrm{L}$ whole blood samples, using the TIANamp Blood DNA Kit (TIANGEN). The quantity and integrity of DNA were analyzed by electrophoresis on $1 \%$ agarose gel with ethidium bromide staining. 


\section{Polymerase chain reaction (PCR) conditions}

To obtain the myostatin genomic sequence, we designed 3 primer pairs (P1-P6) based on the GenBank myostatin sequence AF320998, using the Primer 5.0 software. To amplify the promoter, we designed primers (P7-P8) based on the GenBank myostatin sequence AF348479 (Spiller et al., 2002). To amplify the mRNA, we designed primers (P9-P10) based on the GenBank myostatin sequence AY160688. All primers used in this study are listed in Table 1.

\begin{tabular}{|c|c|c|c|c|}
\hline Name & Position (bp) & Primer sequence & Annealing temperature $\left({ }^{\circ} \mathrm{C}\right)$ & Size (bp) \\
\hline P1 & $11 \rightarrow 1170$ & 5'-AGTATAAAAGATTCACTGGTGTGGC-3' & 58.0 & 1160 \\
\hline P2 & (AF320998) & 5'-TGTGTTTACTTCCTTATTGCTCTTACTA-3' & & \\
\hline P3 & $1054 \rightarrow 3588$ & 5'-AGGGTTTTTATGGTCTTCACAGAGTATC-3' & 58.0 & 2535 \\
\hline P4 & (AF320998) & 5'-AAACAGAAGTAAATACAAGCATAGATAAGCC-3' & & \\
\hline P5 & $3560 \rightarrow 6621$ & 5'-CTTATCTATGCTTGTATTTACTTCTGTTTTC-3' & 62.0 & 3062 \\
\hline P6 & (AF320998) & 5'-AATTGTTTCTACACATTGGATGTAAGAA-3' & & \\
\hline P7 & $8721 \rightarrow 10312$ & 5'-CAGGGCATCTGGTTTGTGTC-3' & 61.7 & 1592 \\
\hline P8 & (AF348479) & 5'-TGCCTGCCCAGTCTGAGAGA-3' & & \\
\hline P9 & $307 \rightarrow 1125$ & 5'-GACGGCTCCTTGGAAGACGAT-3' & 60.4 & 819 \\
\hline P10 & (AY160688) & 5'-TGAACACCCACAGCGATCTA-3' & & \\
\hline
\end{tabular}

Exons 1, 2, and 3 are located at base pairs, 152-524, 2365-2738, 4772-5152, respectively (GenBank accession No. AF320998).

The PCR was performed in a $25-\mu \mathrm{L}$ reaction volume, containing $100 \mathrm{ng}$ genomic DNA, $1 \mathrm{X}$ Taq reaction buffer, $5 \mathrm{nmol}$ dNTPs, 20 pmol each primer, and 0.25 units Taq DNA polymerase (Promega).

\section{Sequencing and analysis}

The myostatin gene and promoter were obtained by PCR from Qinchuan and Red Angus cattle genomic DNA. The DNA fragments were cloned into a pMD-18T vector (TaKaRa) and then sequenced with an ABI PRISM 3730 DNA sequencer (Applied Biosystems). Sequence analysis was conducted using the DNAMAN software, version 5.2.2.

mRNA was isolated from the skeletal muscle of Qinchuan and Red Angus cattle with TRIZOL $^{\circledR}$ Reagent (Invitrogen) following manufacturer protocols. cDNA was synthesized with the RevertAid First-Strand cDNA Synthesis Kit (Fermentas). Myostatin-specific cDNA was amplified with the primer P9-P10 and then sequenced to confirm the exon/intron boundaries of the gene.

\section{RESULTS}

We first checked the integrity of the genomic DNA on $1 \%$ agarose gel electrophoresis. The sequences were also checked manually by splicing and removal of the sequencing primer. The sequences were then compared with those of other bovine breeds that have been deposited to GenBank (B. indicus accession No. AY794986; B. taurus accession No. AF320998). Observed variations between the sequences of the Qinchuan breeds and Bos taurus are shown in Table 2. A total of 69 SNPs were identified, only 1 of which was an insertion mutation in Qinchuan cattle. Furthermore, there was a total of 7 SNPs in exon 3: nt111 $(\mathrm{G} \rightarrow \mathrm{C}), \mathrm{nt179}$ $(\mathrm{T} \rightarrow \mathrm{C})$, nt197 $(\mathrm{T} \rightarrow \mathrm{A})$, nt212 $(\mathrm{A} \rightarrow \mathrm{G})$, nt414 $(\mathrm{T} \rightarrow \mathrm{C})$, nt1077 $(\mathrm{A} \rightarrow \mathrm{C})$, and nt1083 $(\mathrm{C} \rightarrow \mathrm{T})$ (Figures 1, 2, and 3, and Table 2). 
Table 2. Polymorphism of myostatin gene sequence.

\begin{tabular}{|c|c|c|c|c|c|}
\hline $\begin{array}{l}\text { Base position } \\
\text { (AF320998) }\end{array}$ & $\begin{array}{c}\text { Bos taurus } \\
\text { sequence (AF320998) }\end{array}$ & $\begin{array}{c}\text { Bos indicus } \\
\text { sequence (AY794986) }\end{array}$ & $\begin{array}{l}\text { Qinchuan cattle } \\
\text { sequence }\end{array}$ & Red Angus cattle sequence & Location \\
\hline 262 & G & $\mathrm{G} / \mathrm{C}$ & $\mathrm{G} / \mathrm{C}$ & G & Exon 1 \\
\hline 330 & $\mathrm{~T}$ & $\mathrm{~T}$ & $\mathrm{~T} / \mathrm{C}$ & $\mathrm{T}$ & \\
\hline 348 & $\mathrm{~T}$ & $\mathrm{~T}$ & $\mathrm{~T} / \mathrm{A}$ & $\mathrm{T}$ & \\
\hline 363 & A & A & $\mathrm{A} / \mathrm{G}$ & A & \\
\hline 807 & $\mathrm{~T}$ & $\mathrm{~T}$ & - & - & Intron 1 \\
\hline 870 & Insertion & $\mathrm{T}$ & $\mathrm{T}$ & $\mathrm{T}$ & \\
\hline 917 & A & A & $\mathrm{A} / \mathrm{T}$ & $\mathrm{A} / \mathrm{T}$ & \\
\hline 998 & $\mathrm{~T}$ & $\mathrm{~T}$ & $\mathrm{~T} / \mathrm{C}$ & $\mathrm{T} / \mathrm{C}$ & \\
\hline 1020 & G & G & $\mathrm{G} / \mathrm{A}$ & $\mathrm{G}$ & \\
\hline 1045 & $\mathrm{~T}$ & - & - & - & \\
\hline 1066 & $\mathrm{G}$ & $\mathrm{T}$ & $\mathrm{T} / \mathrm{G}$ & $\mathrm{G}$ & \\
\hline 1201 & G & $\mathrm{G}$ & $\mathrm{G} / \mathrm{A}$ & G & \\
\hline 1229 & Insertion & GAGTAGATTATGGCTT & GAGTAGATTATGGCTT & Insertion & \\
\hline 1331 & G & $\mathrm{T}$ & $\mathrm{T} / \mathrm{G}$ & $\mathrm{T}$ & \\
\hline 1405 & A & A & $\mathrm{A} / \mathrm{G}$ & $\mathrm{A}$ & \\
\hline 1423 & G & G & $\mathrm{G} / \mathrm{A}$ & G & \\
\hline 1458 & $\mathrm{C}$ & $\mathrm{C}$ & $\mathrm{C} / \mathrm{T}$ & $\mathrm{C}$ & \\
\hline 1661 & $\mathrm{C}$ & $\mathrm{C}$ & $\mathrm{C} / \mathrm{T}$ & $\mathrm{C}$ & \\
\hline 1664 & A & A & $\mathrm{A} / \mathrm{T}$ & A & \\
\hline 1981 & $\mathrm{C}$ & A & A & A & \\
\hline 1990 & $\mathrm{C}$ & $\mathrm{T}$ & $\mathrm{T}$ & $\mathrm{T}$ & \\
\hline 2137 & $\mathrm{~T}$ & G & $\mathrm{G} / \mathrm{T}$ & G & \\
\hline 2284 & Insertion & - & $\mathrm{A} /-$ & A & \\
\hline 2311 & C & $\mathrm{C}$ & $\mathrm{T} / \mathrm{C}$ & $\mathrm{T}$ & \\
\hline 2316 & A & A & $\mathrm{A} / \mathrm{G}$ & A & \\
\hline 2343 & Insertion & - & $-/ \mathrm{T}$ & $\mathrm{T}$ & \\
\hline 2405 & $\mathrm{~T}$ & $\mathrm{C}$ & $\mathrm{C}$ & $\mathrm{C}$ & Exon 2 \\
\hline 2854 & G & $\mathrm{T}$ & $\mathrm{G} / \mathrm{T}$ & G & Intron 2 \\
\hline 2855 & $\mathrm{C}$ & $\mathrm{C}$ & $\mathrm{T} / \mathrm{C}$ & $\mathrm{T}$ & \\
\hline 2856 & A & A & $\mathrm{G} / \mathrm{A}$ & G & \\
\hline 2882 & $\mathrm{~T}$ & $\mathrm{~T}$ & $\mathrm{C} / \mathrm{T}$ & $\mathrm{C}$ & \\
\hline 2974 & $\mathrm{C}$ & $\mathrm{C}$ & $\mathrm{C} / \mathrm{T}$ & $\mathrm{T}$ & \\
\hline 3035 & G & A & $\mathrm{A} / \mathrm{G}$ & A & \\
\hline 3059 & A & A & $\mathrm{C} / \mathrm{A}$ & $\mathrm{C}$ & \\
\hline 3096 & $\mathrm{~T}$ & $\mathrm{~T}$ & $\mathrm{~T} / \mathrm{A}$ & A & \\
\hline 3162 & G & A & A & A & \\
\hline 3215 & $\mathrm{~T}$ & A & A & A & \\
\hline 3227 & $\mathrm{~T}$ & G & G & G & \\
\hline 3293 & $\mathrm{C}$ & $\mathrm{C}$ & $\mathrm{C} / \mathrm{T}$ & $\mathrm{C}$ & \\
\hline 3628 & G & $\mathrm{T}$ & $\mathrm{T}$ & $\mathrm{T}$ & \\
\hline 3674 & A & A & G & G & \\
\hline 3691 & A & A & $\mathrm{A} / \mathrm{T}$ & $\mathrm{T}$ & \\
\hline 3768 & $\mathrm{~T}$ & A & $\mathrm{A}$ & A & \\
\hline 3838 & A & A & A & G & \\
\hline 3908 & A & A & A & G & \\
\hline 3919 & $\mathrm{~T}$ & $\mathrm{~T}$ & $\mathrm{~T}$ & $\mathrm{C}$ & \\
\hline 4112 & $\mathrm{C}$ & $\mathrm{C}$ & $\mathrm{T}$ & $\mathrm{T}$ & \\
\hline 4204 & A & - & - & - & \\
\hline 4290 & $\mathrm{~T}$ & $\mathrm{~T}$ & $\mathrm{~T} / \mathrm{C}$ & $\mathrm{C}$ & \\
\hline 4334 & $\mathrm{G}$ & $\mathrm{C}$ & $\mathrm{G} / \mathrm{C}$ & $\mathrm{G}$ & \\
\hline 4355 & $\mathrm{G}$ & A & A & A & \\
\hline 4372 & A & $\mathrm{G}$ & $\mathrm{A} / \mathrm{G}$ & A & \\
\hline 4421 & $\mathrm{~T}$ & $\mathrm{C}$ & $\mathrm{C}$ & $\mathrm{C}$ & \\
\hline 4432 & $\mathrm{~T}$ & $\mathrm{C}$ & $\mathrm{T} / \mathrm{C}$ & $\mathrm{T}$ & \\
\hline 4492 & $\mathrm{G}$ & $\mathrm{G}$ & $\mathrm{G} / \mathrm{C}$ & $\mathrm{C}$ & \\
\hline 4530 & $\mathrm{G}$ & $\mathrm{G}$ & $\mathrm{G} / \mathrm{C}$ & $\mathrm{G}$ & \\
\hline
\end{tabular}

Continued on next page 
Table 2. Continued.

\begin{tabular}{|c|c|c|c|c|c|}
\hline $\begin{array}{l}\text { Base position } \\
\text { (AF320998) }\end{array}$ & $\begin{array}{c}\text { Bos taurus } \\
\text { sequence (AF320998) }\end{array}$ & $\begin{array}{c}\text { Bos indicus } \\
\text { sequence (AY794986) }\end{array}$ & $\begin{array}{l}\text { Qinchuan cattle } \\
\text { sequence }\end{array}$ & Red Angus cattle sequence & Location \\
\hline 4571 & G & G & $\mathrm{G} / \mathrm{A}$ & G & \\
\hline 4691 & Insertion & $\mathrm{T}$ & $-/ \mathrm{T}$ & $\mathrm{T}$ & \\
\hline 4698 & $\mathrm{~T}$ & $\mathrm{~T}$ & $\mathrm{~T}$ & $\mathrm{~T} / \mathrm{C}$ & \\
\hline 5101 & A & $\mathrm{T}$ & $\mathrm{A} / \mathrm{C}$ & A & Exon 3 \\
\hline 5107 & $\mathrm{C}$ & $\mathrm{T}$ & $\mathrm{C} / \mathrm{T}$ & $\mathrm{C}$ & \\
\hline 5179 & $\mathrm{C}$ & A & $\mathrm{C} / \mathrm{A}$ & $\mathrm{C}$ & 3'-UTR \\
\hline 5253 & $\mathrm{~T}$ & $\mathrm{~T}$ & $\mathrm{~T}$ & $\mathrm{C}$ & \\
\hline 5303 & A & A & $\mathrm{A} / \mathrm{C}$ & A & \\
\hline 5311 & A & $\mathrm{T}$ & $\mathrm{T} / \mathrm{A}$ & $\mathrm{T}$ & \\
\hline 5332 & $\mathrm{C}$ & A & $\mathrm{A} / \mathrm{C}$ & A & \\
\hline 5353 & A & $\mathrm{C}$ & $\mathrm{C} / \mathrm{A}$ & $\mathrm{C}$ & \\
\hline 5406 & G & $\mathrm{C}$ & $\mathrm{C}$ & $\mathrm{C}$ & \\
\hline 5415 & $\mathrm{~T}$ & $\mathrm{C}$ & $\mathrm{C} / \mathrm{T}$ & $\mathrm{C}$ & \\
\hline 5494 & C & $\mathrm{T}$ & $\mathrm{T}$ & $\mathrm{T}$ & \\
\hline 5639 & $\mathrm{G}$ & A & A & A & \\
\hline 5655 & A & $\mathrm{G}$ & $\mathrm{G}$ & $\mathrm{G}$ & \\
\hline 5662 & $\mathrm{G}$ & A & A & A & \\
\hline 5769 & A & $\mathrm{G}$ & $\mathrm{G}$ & $\mathrm{G}$ & \\
\hline 5863 & $\mathrm{~T}$ & $\mathrm{~T}$ & $\mathrm{C} / \mathrm{T}$ & $\mathrm{C}$ & \\
\hline
\end{tabular}

$(-)=$ Del.

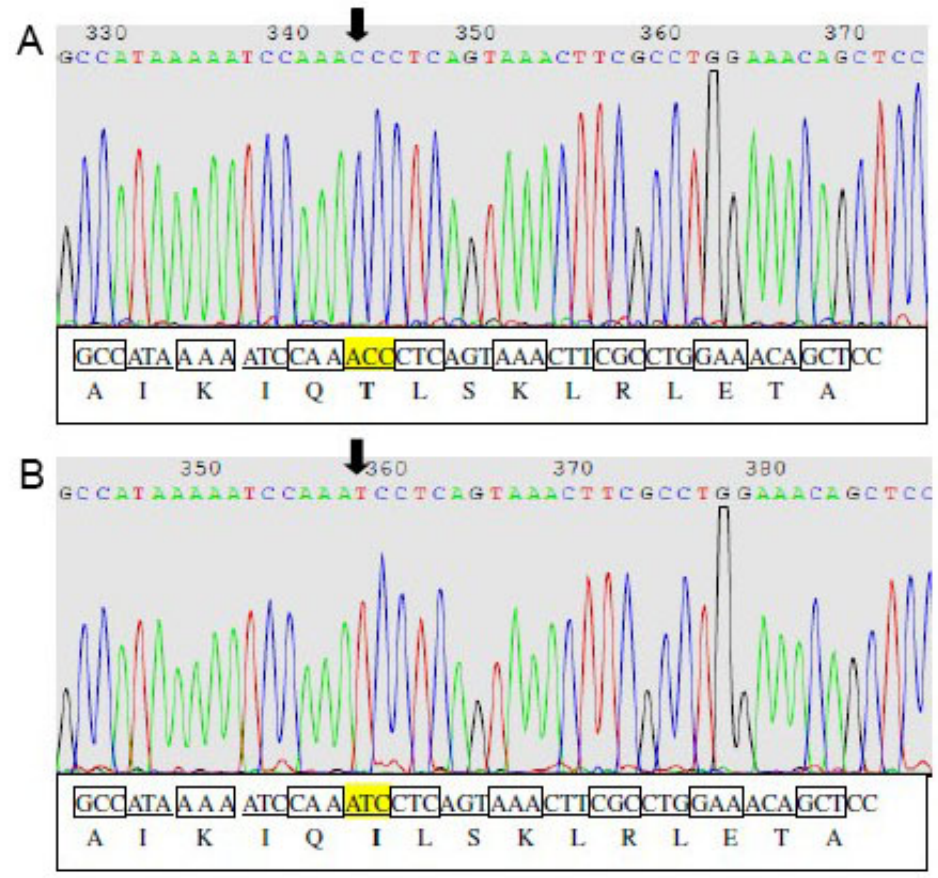

Figure 1. Nucleotide sequence diagram of nt179 $(\mathrm{T} \rightarrow \mathrm{C})$ results in I60T mutant. A. Normal cattle; B. mutation cattle. 


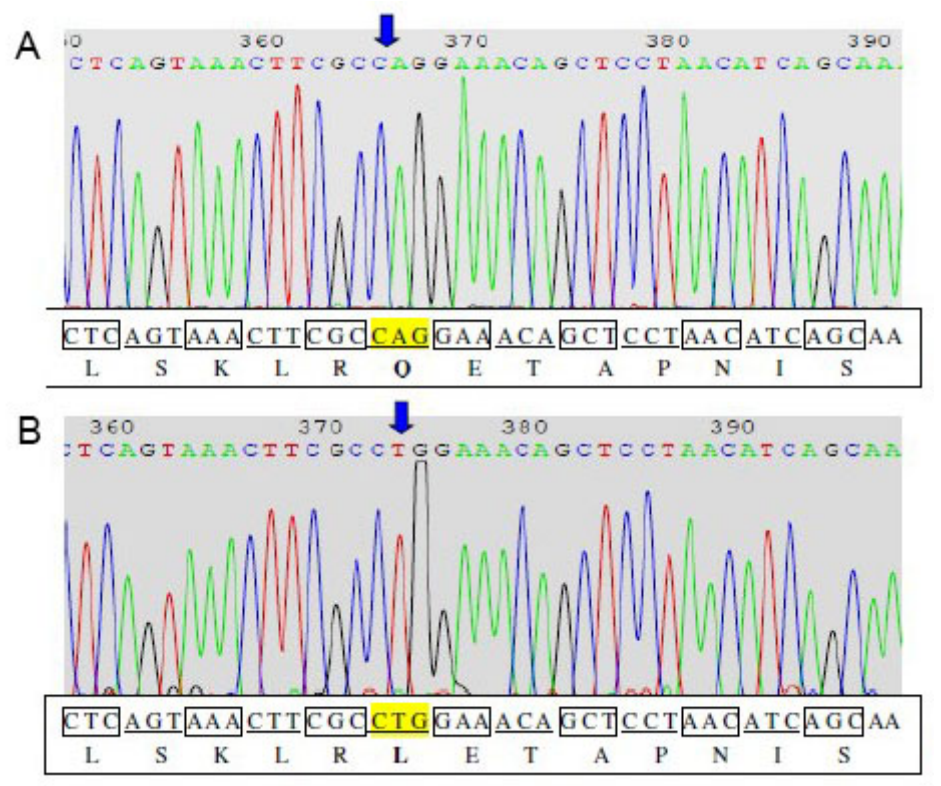

Figure 2. Nucleotide sequence diagram of nt197 $(\mathrm{T} \rightarrow \mathrm{A})$ results in L66Q mutant. A. Normal cattle; B. mutation cattle.

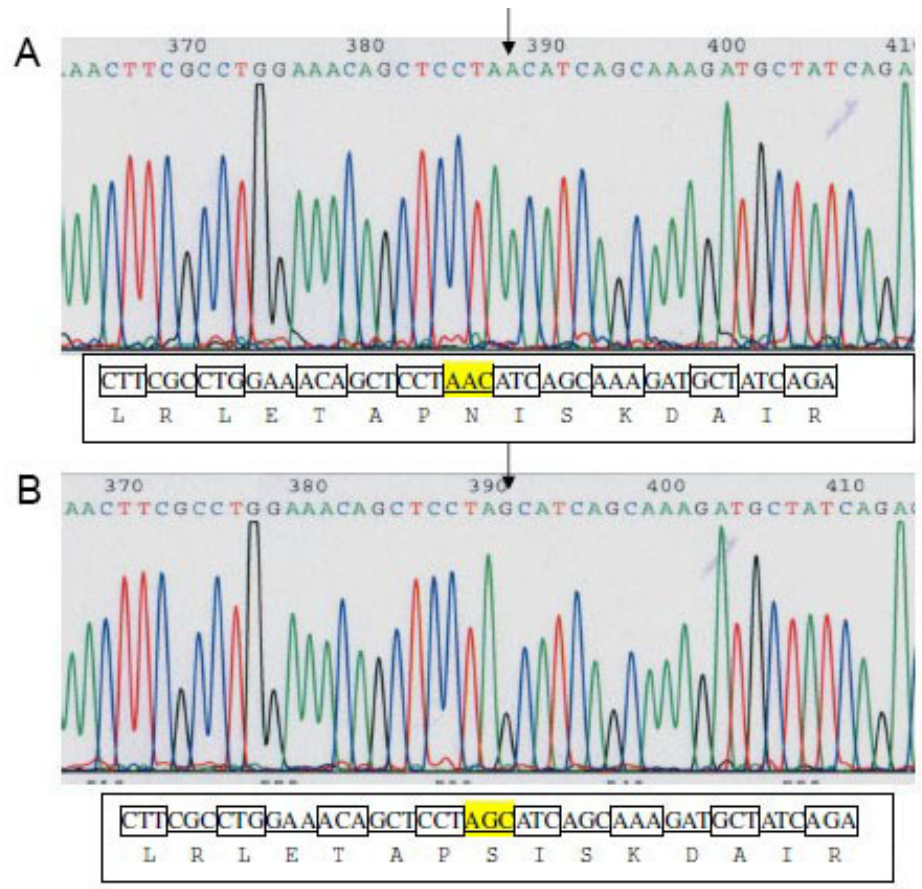

Figure 3. Nucleotide sequence diagram of nt212 $(\mathrm{A} \rightarrow \mathrm{G})$ results in N71S mutant. A. Normal cattle; B. mutation cattle. 
There were 3 base mutations in exon 1 resulting in amino acid changes in the amino acids I60T, L66Q, and N71S. The remaining mutations observed occurred in the first 3 codons and were synonymous; that is, they did not cause changes in amino acids.

One insertion unique to 3 Qinchuan individuals (16-GAGTAGATTATGGCTT) was found in the first 705-bp intron of the myostatin gene. This insertion sequence (GAGTAGATTATGGCTT) (He et al., 2011) is the same as that reported by Tantia et al. (2006).

The results also showed that there were 50 SNPs between Qinchuan and Red Angus cattle breeds, including nt111 $(\mathrm{G} \rightarrow \mathrm{C})$, nt179 $(\mathrm{T} \rightarrow \mathrm{C})$, nt197(T $\rightarrow \mathrm{A})$, nt212(A $\rightarrow \mathrm{G})$, nt1077 $(\mathrm{A} \rightarrow \mathrm{C})$, and $\mathrm{nt} 1083(\mathrm{C} \rightarrow \mathrm{T})$, in exons 1 and 3 . The 3 base mutations in exon 1 caused amino acid changes in amino acids I60T, L66Q, and N71S, whereas the other mutations were synonymous.

There were 18 and 14 SNPs in the Qinchuan myostatin gene promoter compared to the published GenBank sequences (accession No. AF348479) and that of the Red Angus cattle breeds, respectively (Table 3 ).

\begin{tabular}{|c|c|c|c|c|}
\hline $\begin{array}{l}\text { Base position } \\
\text { (AF348479) }\end{array}$ & $\begin{array}{c}\text { Bos taurus } \\
\text { sequence (AF348479) }\end{array}$ & $\begin{array}{c}\text { Bos taurus } \\
\text { sequence (AJ438578) }\end{array}$ & $\begin{array}{l}\text { Qinchuan cattle } \\
\text { sequence }\end{array}$ & Red Angus cattle sequence \\
\hline 9157 & $\mathrm{~T}$ & & C & $\mathrm{T}$ \\
\hline 9199 & C & C & $\mathrm{T}$ & C \\
\hline 9213 & C & C & - & C \\
\hline 9296 & $\mathrm{~T}$ & $\mathrm{~T}$ & C & $\mathrm{T}$ \\
\hline 9305 & A & A & G & A \\
\hline 9308 & C & C & G & C \\
\hline 9339 & A & A & G & A \\
\hline 9343 & $\mathrm{~T}$ & $\mathrm{~T}$ & $\mathrm{C}$ & $\mathrm{T}$ \\
\hline 9348 & $\mathrm{~T}$ & $\mathrm{~T}$ & $\mathrm{C}$ & $\mathrm{T}$ \\
\hline 9357 & C & $\mathrm{T}$ & $\mathrm{T}$ & $\mathrm{T}$ \\
\hline 9431 & G & A & A & A \\
\hline 9442 & A & A & G & A \\
\hline 9499 & A & A & $\mathrm{T}$ & A \\
\hline 9598 & C & G & G & G \\
\hline 9607 & $\mathrm{~T}$ & $\mathrm{~T}$ & C & $\mathrm{T}$ \\
\hline 10029 & $\mathrm{~T}$ & $\mathrm{~T}$ & G & $\mathrm{T}$ \\
\hline 10042 & C & A & A & A \\
\hline 10047 & C & C & A & C \\
\hline
\end{tabular}

$(-)=$ Del.

\section{DISCUSSION}

Qinchuan cattle have been popular farming and meat-utility breeds in China for thousands of years (Pang et al., 2011). This breed is characterized by a number of favorable traits, including a tall body, good meat quality, genetic stability, and adaptability. However, they also have relatively low meat production, and their hindquarters are underdeveloped and grow slowly. Such shortcomings can have serious negative impacts on the economic benefits of Qinchuan when in competition with common foreign commercial beef cattle breeds (Zhang et al., 2007; Han et al., 2008), for example, Red Angus cattle. It has therefore become necessary to improve the meat productivity in Qinchuan cattle breeds while maintaining their other favorable characteristics. As reported previously, the myostatin gene negatively regulates the skeletal muscle, in which the loss or congenital absence of myostatin function is associated 
with an increase in muscle mass. In order to improve the meat production performance of Qinchuan as soon as possible and develop a better breed of beef cattle, we investigated muscle production related to single nucleotide polymorphisms in the myostatin gene and its promoter of the Qinchuan and Red Angus cattle breeds. After obtaining the sequences of both breeds, we observed a high degree of conservation in cattle myostatin.

Our results suggest that although the 2 breeds have different growth and development levels, it is unlikely that this is due to nucleotide mutations in the myostatin gene. Some SNPs, $\mathrm{nt} 414(\mathrm{~T} \rightarrow \mathrm{C})$ and/or nt1083 $(\mathrm{C} \rightarrow \mathrm{T})$, in exon 3 of the myostatin genes of both the Qinchuan and Red Angus breeds have also been observed in European cattle breeds, the Nellore breed, and in Brazilian Murrah buffalo (Bubalus bubalis) (Dunner et al., 2003; Mota et al., 2006). This suggests that these 2 sites have a high level of polymorphism, which has previously been generally observed in the myostatin gene of cattle (Grobet et al., 1998).

In the Nellore breed, 11 new polymorphisms were identified in the 3 exons, in which 4 were synonymous mutations, including $\mathrm{nt} 111(\mathrm{G} \rightarrow \mathrm{T})$, and 7 were nonsynonymous mutations resulting in amino acid changes (Grisolia et al., 2009). In the present study, we found that polymorphisms at nt111 $(\mathrm{G} \rightarrow \mathrm{C})$ in Qinchuan and Red Angus cattle breeds also resulted in synonymous mutations. The details of SNPs are useful for population diversity and muscle production analysis within cattle breeds. Our results therefore contribute important data to help develop a new Qinchuan breed line through molecular breeding approaches.

\section{ACKNOWLEDGMENTS}

Research supported by the National Natural Science Foundation of China (\#31260287 and \#31201867) and the Key Scientific and Technological Special Program for the Culture of Disease-Resistant Transgenic Cattle Species, Government of China (\#2008ZX08007-004).

\section{REFERENCES}

Baron EE, Lopes MS, Mendonça D and da Câmara Machado A (2012). SNP identification and polymorphism analysis in exon 2 of the horse myostatin gene. Anim. Genet. 43: 229-232.

Boman IA and Våge DI (2009). An insertion in the coding region of the myostatin (MSTN) gene affects carcass conformation and fatness in the Norwegian Spaelsau (Ovis aries). BMC Res. Notes 2: 98.

Boman IA, Klemetsdal G, Blichfeldt T, Nafstad O, et al. (2009). A frameshift mutation in the coding region of the myostatin gene (MSTN) affects carcass conformation and fatness in Norwegian White Sheep (Ovis aries). Anim. Genet. 40: 418-422.

Clop A, Marcq F, Takeda H, Pirottin D, et al. (2006). A mutation creating a potential illegitimate microRNA target site in the myostatin gene affects muscularity in sheep. Nat. Genet. 38: 813-818.

Dunner S, Miranda ME, Amigues Y, Cañón J, et al. (2003). Haplotype diversity of the myostatin gene among beef cattle breeds. Genet. Sel. Evol. 35: 103-118.

Grisolia AB, D’Angelo GT, Porto Neto LR, Siqueira F, et al. (2009). Myostatin (GDF8) single nucleotide polymorphisms in Nellore cattle. Genet. Mol. Res. 8: 822-830.

Grobet L, Martin LJ, Poncelet D, Pirottin D, et al. (1997). A deletion in the bovine myostatin gene causes the doublemuscled phenotype in cattle. Nat. Genet. 17: 71-74.

Grobet L, Poncelet D, Royo LJ, Brouwers B, et al. (1998). Molecular definition of an allelic series of mutations disrupting the myostatin function and causing double-muscling in cattle. Mamm. Genome 9: 210-213.

Han RH, Zan LS, Yang DP and Hao RC (2008). SNPs detection of IGF2 gene and its relationship with carcass and meat quality traits in Qinchuan cattle. Yi Chuan 30: 1579-1584.

He Y, Wu Y, Lan Z, Liu Y, et al. (2011). Molecular analysis of the first intron in the bovine myostatin gene. Mol. Biol. Rep. 38: 4643-4649. 
Joulia-Ekaza D and Cabello G (2006). Myostatin regulation of muscle development: molecular basis, natural mutations, physiopathological aspects. Exp. Cell Res. 312: 2401-2414.

Kambadur R, Sharma M, Smith TP and Bass JJ (1997). Mutations in myostatin (GDF8) in double-muscled Belgian Blue and Piedmontese cattle. Genome Res. 7: 910-916.

Karim L, Coppieters W, Grobet L, Valentini A, et al. (2000). Convenient genotyping of six myostatin mutations causing double-muscling in cattle using a multiplex oligonucleotide ligation assay. Anim. Genet. 31: 396-399.

Marchitelli C, Savarese MC, Crisa A, Nardone A, et al. (2003). Double muscling in Marchigiana beef breed is caused by a stop codon in the third exon of myostatin gene. Mamm. Genome 14:392-395.

McPherron AC and Lee SJ (1997). Double muscling in cattle due to mutations in the myostatin gene. Proc. Natl. Acad. Sci. U. S. A. 94: 12457-12461.

McPherron AC, Lawler AM and Lee SJ (1997). Regulation of skeletal muscle mass in mice by a new TGF-beta superfamily member. Nature 387: 83-90.

Mosher DS, Quignon P, Bustamante CD, Sutter NB, et al. (2007). A mutation in the myostatin gene increases muscle mass and enhances racing performance in heterozygote dogs. PLoS Genet. 3: e79.

Mota LSLS, Curi RA, Palmieri DA, Borges AS, et al. (2006). Sequence characterization of coding regions of the myostatin gene (GDF8) from Brazilian Murrah buffaloes (Bubalus bubalis) and comparison with the Bos taurus sequence. Genet. Mol. Biol. 29: 179-182.

Pang Y, Wang J, Zhang C, Lei C, et al. (2011). The polymorphisms of bovine VEGF gene and their associations with growth traits in Chinese cattle. Mol. Biol. Rep. 38: 755-759.

Schuelke M, Wagner KR, Stolz LE, Hubner C, et al. (2004). Myostatin mutation associated with gross muscle hypertrophy in a child. N. Engl. J. Med. 350: 2682-2688.

Smith JA, Lewis AM, Wiener P and Williams JL (2000). Genetic variation in the bovine myostatin gene in UK beef cattle: allele frequencies and haplotype analysis in the South Devon. Anim. Genet. 31: 306-309.

Spiller MP, Kambadur R, Jeanplong F, Thomas M, et al. (2002). The myostatin gene is a downstream target gene of basic helix-loop-helix transcription factor MyoD. Mol. Cell Biol. 22: 7066-7082.

Tantia MS, Vijh RK, Kumar ST, Mishra B, et al. (2006). Comparative analysis of GDF 8 (myostatin) in Bos indicus and Bos taurus. DNA Seq. 17: 311-313.

Zhang RF, Chen H, Lei CZ, Zhang CL, et al. (2007). Association between polymorphisms of MSTN and MYF5 genes and growth traits in three Chinese cattle breeds. Asian-Aust. J. Anim. Sci. 20: 1798-1804. 